\title{
Viewing Health: Asclepia in their Natural Settings
}

Petsalis-Diomidis has recently argued in her study of Aelius Aristides' descriptions of the Asclepion at Pergamum that his visual experience at the site, as well as other sanctuaries, helped to facilitate the ritual facets of the healing process. ${ }^{1}$ The sense of sight allowed for a connection between the pilgrim and Asclepius to be made, which was achieved through viewing three sacred features: a sanctified area associated with the deity, such as his birthplace; the objects and votive offerings donated at the sites; and processions and rituals enacted in the sanctuaries. ${ }^{2}$ Although there is no doubt that seeing and participating in these devotional activities played a significant role in the healing event, the natural landscape surrounding the sanctuaries was also visible to the pilgrims. Viewing it, too, I will argue, was vital for the restoration of body and mind, as the Roman writer Vitruvius indicates in his book On Architecture. When commenting on the construction of colonnades at theatres, he said, the spaces between colonnades that are open to the sky should have green plots because they are healthy for the eyes. ${ }^{3}$ Moreover, throughout his text, Vitruvius wrote about the placement of structures and rooms that took into consideration light, temperature and winds to promote good health. ${ }^{4}$ He was not alone in expressing these ideas; many Greco-Roman medical and nonmedical writers mentioned the importance of geographic location and water quality for the health of a population. ${ }^{5}$ Yet, what is significant about the statement of Vitruvius' is that he indicates that the sense of sight and viewing natural vistas and colours were important for the promotion of health, or at least that of the eyes, because the air from these is 'subtle and rarefied' and 'when it flows through the body helps remove thick humours in the eyes, clearing vision. ${ }^{6}$ In this paper, it is maintained that the Greeks and Romans believed there existed a

\footnotetext{
${ }^{1}$ Petsalis-Diomidis 2005

${ }^{2}$ Petsalis-Diomidis 2005: 188-189. These rituals were part of a process of a visual dialogue described by Petridou 2013, Petsalis-Diomidis 2008, and Elsner 2007 that allowed a pilgrim to commune with the god through ritual participation.

${ }^{3}$ De Architectura 5.9.5 'The open spaces which are between the colonnades under the open sky, are to be arranged with green plots; because walks in the open are very healthy, first for the eyes, because from the green plantations, the air being subtle and rarefied, flows into the body as it moves, clears the vision, and so by removing the thick humour from the eyes, leaves the glance defined and the image clearly marked.' 'Media vero spatia quae erunt subdiu inter porticus, adornanda viridibus videntur, quod hypaethroe ambulationes habent magnam salubritatem. Et primum oculorum, quod ex viridibus subtilis et extenuatus aer propter motionem corporis influens perlimat speciem et ita auferens ex oculis umorem crassum, aciem tenuem et acutam speciem relinquit.' (translation: Granger)

${ }^{4}$ E.g. De Arch. 1.10; 6.1.1-12; 6.4.1-2

${ }^{5}$ E.g. Hippocrates Airs Waters Places; Cato De Agricultura; Varro Re Res Rustica

${ }^{6}$ De Arch. 5.9.5, see footnote 3
} 
relationship between vision and the landscape that helped to restore the mind and the body, particularly in healing sanctuaries dedicated to Asclepius.

A study of this nature adds a unique approach to our conception of events in GraecoRoman healing sanctuaries. Much scholarly attention has been devoted to the rites and practices of incubation that occurred in these ritual spaces; while archaeological examinations concentrate on the votive body parts and monumental structures found in the sites. ${ }^{7}$ In comparison, the natural environments surrounding the Asclepia and the pilgrims' encounters with them have remained unnoticed. Yet, the Hippocratic writer of Airs Waters Places, as Lo Presti argues, explained that humans are both bound by a similarity to and a relationship with the environment. In this relationship, humans have the power to adapt to and eventually control their natural surroundings. ${ }^{8}$ This raises the question whether the supplicants who visited sanctuaries felt an inextricable link to their surrounding landscape when they travelled to the spaces to attain a cure for their ailment, as the Hippocratic writer believes. Considering the pilgrims' encounter with views of the landscape presents us with an opportunity to develop a more rounded appreciation of what it was like to visit a sanctuary in the past, extending beyond ritual activity. It also allows us to determine the relationship people had with the environment and how the sense of sight helped to enhance a person's mental and physical well-being.

To ascertain the relationship between views and health in the ancient world, an interdisciplinary methodology involving the examination of literature and landscapes will be employed in this study. This paper begins with a discussion of ancient texts that mention health and the environment, followed by a description of the landscapes surrounding healing sanctuaries located in Greece, Asia Minor and Magna Graecia. The landscapes are assessed to determine what scenery was visible from the sites. Once the background information is presented, a discussion follows on about new approaches in archaeological theory that can assist with interpretations of the Greek and Roman understanding of the relationship between vision and landscape and how this relationship could offer health to the patient.

Before, I explore these issues, I will explain what led me to consider the questions addressed in this paper. The archaeologists Vincent Scully and Roger Tomlinson wrote separately about their experiences visiting Greek healing sanctuaries, and both described similar effects the mountainous scenery had on their health. Viewing the landscape made them relax, which ultimately benefitted their health. Their experiences were shaped by their sense

\footnotetext{
${ }^{7}$ e.g. Aleshire 1989; Hughes 2008; Reithmüller 2005; Wickkiser 2008

8 2012: 176, 181-188
} 
perceptions, with sight and sound, or rather lack of noise, being most prominent in their descriptions. ${ }^{9}$ In spite of the fact that these scholars report similar effects and views, it cannot be assumed that the Graeco-Roman pilgrim would have had the same sensory experiences. Conceptions of how the senses function differs over time and between cultures. ${ }^{10}$ Scully's and Tomlinson's are informed through a modern, western, cultural lens, and they were likely to have been in a physically healthy state. A pilgrim, on the other hand, was probably ill and/or disabled, which would have affected their sensory stimulation and encounters with the landscape.

Although it would be beneficial to access information about other sensory stimuli smells, sounds and textures - accessible in healing sanctuaries, the primary literature describing these sites is vague. The archaeological reports of these places, if available, lack information on the botanical and faunal remains, making it difficult to establish what plants and animals were present at the sites. Having this information alerts us to smells and sounds, such as birdsongs, which may have been encountered. Yet, the mountains and bodies of water have changed little over time, so views of landscapes and seascapes can be ascertained, making it possible to determine what people would have seen from the sanctuaries.

\section{Landscapes and Health}

Salubrious environments were described in medical texts from the fifth century B.C. onwards, most notably in the Hippocratic work Airs Waters Places, which explained how specific settings, prevailing winds and water and air quality effected the humoral constitution of the inhabitants occupying the areas described. Although the information given in the medical texts was specific, general statements of what constituted a healthy environment, as briefly mentioned in the introduction, are found across a range of literary genres, suggesting the possibility of a cross-pollination of ideas between physicians and the public concerning the powers of landscapes. This is particularly common in the literature of the Roman era, from the mid-third century BC onwards, which is the same period we see a growth in the construction and use of Greek Asclepia. It is, therefore, possible that what was being described in the texts correlates with the pilgrims' encounters with the natural surroundings of ritual areas.

To provide some background information to how Graeco-Roman authors understood the connection between the environment and health, I begin with a statement by Varro (c. 116-27

\footnotetext{
${ }^{9}$ Scully 1979: 206; Tomlinson 1976: 97

${ }^{10}$ For an overview see Howes and Classen 2014: 38-61
} 
BC), who, like the Hippocratic writer, maintained that unwholesome land and buildings could be made better in consideration of the setting.

'For if the farm is unwholesome on account of the nature of the land or the water, from the miasma which is exhaled in some spots; or if, on account of the climate, the land is too hot or the wind is not salubrious, these faults can be alleviated by the science and the outlay of the owner. The situation of the buildings, their size, the exposure of the galleries, the doors and the windows are matters of highest importance. Did not the famous physician Hippocrates, during a great pestilence save no one farm but many cities by his skill? But why do I speak of him? Did not our friend Varro, when the army and fleet were at Corcyra, and all the houses were crowded with the sick and the dead, by cutting new windows to admit the north wind, and shutting out the infected winds by changing the position of the doors and other precautions of the same kind, bring back him comrades and his servants in good health?'11

Here we see that altering structures to face a new aspect and different winds improved the health of people suffering from a disease outbreak. It corresponds to the advice given in medical texts, indicating he likely had some knowledge of them or the concepts were widespread. However, other writers gave less specific advice when they described environments that were conducive to a healthy state of being.

Some of the Roman authors' discussions use the term healthy (salubrus), but they provide little to no firm details about how this term was understood. Cato (234-149 BC), for example, advised anyone looking to purchase a farm to ensure that it had a decent climate with fertile soil, necessary for producing crops. He also indicated that it should lie at the foot of a mountain, be south facing and that the 'location should be healthful (locus salubri)'. ${ }^{12}$ Varro also offered similar advice to famers about what they should consider when purchasing land. He advised the potential buyer to ensure that it would 'yield a fair return for the investment in

\footnotetext{
${ }^{11}$ Rust. 1.4. 4-5 'Etenim si propter terram aut aquam odore, quem aliquo loco eructat, pestilentior est fundus, aut propter caeli regionem ager calidior sit, aut ventus non bonus flet, haec vitia emendari solent domini scientia ac sumptu, quod permagni interest, ubi sint positae villae, quantae sint, quo spectent porticibus, ostiis ac fenestris. An non ille Hippocrates medicus in magna pestilentia non unum agrum, sed multa oppida scientia servavit? Sed quid ego illum voco ad testimonium? Non hic Varro noster, cum Corcyrae esset exercitus ac classis et omnes domus repletae essent aegrotis ac funeribus, immisso fenestris novis aquilone et obstructis pestilentibus ianuaque permutata ceteraque eius generis diligentia suos comites ac familiam incolumes reduxit?' (translation Hooper) 12 De Agr. 1.2
} 
money and labour and whether the situation was healthful (utum saluber locus esset)'. ${ }^{13}$ The obvious concern for both writers was to ensure that the soil and climate were suitable for plant growth. Their latter statements about health, however, imply that there was something intrinsic about the landscape that was held to be salubrious. Since neither writer provides any details about what they meant, it is likely that there existed a popular conception of the meaning of the term 'healthy' that was implied by anyone using the word. ${ }^{14}$

Vitruvius was more specific when he explained the healthy placement of cities and fortified towns, advising that they should be located in high regions but, in terms of weather, were neither misty nor frosty. A temperate climate without extremes in temperature was best, and marshy waters were to be avoided. ${ }^{15}$ Other Roman writers expressed the same opinions: Varro said marshy areas caused disease ${ }^{16}$ and Pliny the Elder advised that houses should not be built near marshes or have rivers in front of them. ${ }^{17}$ Four centuries later, Vegetius, who wrote about the Roman army, recommended that fortifications should be built in areas away from marshes. He also warned about environmental extremes and suggested ways of adapting fortifications to these climates. He advised placing forts in shady areas if the location was too sunny and hot; for those in cold regions, he suggested that they should be placed in areas where there was ample sunlight and protections from the wind. ${ }^{18}$

The same requirements - temperate climate, clean air and clear water - were also expected for healing sanctuaries. Plutarch (c. AD 45-120) asked in his work on Roman Questions why the Roman Asclepion was placed outside the city and gave three possible answers. The third claimed the sacred snake from Epidauros chose the location. The second reason was that the Romans imitated the placement of the sanctuary at Epidauros, which was located outside the city. The first one, however, mentions the healthfulness of the location, as he stated:

\footnotetext{
${ }^{13}$ Rust. 1. 2. 8 Duo in primis spectasse videntur Italici homines colendo, possentne fructus pro impensa ac labore redire et utrum saluber locus esset an non. (translation Hooper)

${ }^{14}$ See King 2005 for a discussion on the meaning of health in the Graeco-Roman World.

15 Vitruvius de Architectura 1.4.1 Primum electio loci saluberrimi. Is autem erit excelsus et non nebulosus, non pruinosus regionesque caeli spectans neque aestuosas neque frigidas sed temperatas, deinde sic vitabitur palustris vicinitas. (translation Granger).

${ }^{16}$ Rust. 1. 12. 2 'Sin cogare secundum flumen aedificare, curandum ne adversum eam ponas; hieme enim fiet vehementer frigida et aestate non salubris. Advertendum etiam, siqua erunt loca palustria, et propter easdem causas, et quod crescunt animalia quaedam minuta, quae non possunt oculi consequi, et per aera intus in corpus per os ac nares perveniunt atque efficiunt difficilis morbos.' (translation Hooper)

${ }^{17}$ NH 18.7, novissimus villam in Misenensi posuit C. Marius vii cos. sed peritia castra metandi, sic ut conparatos ei ceteros etiam Sulla Felix caecos fuisse diceret. convenit neque iuxta paludes ponendam esse neque adverso amne, quamquam Homerus omnino eflumine semper antelucanas auras insalubres verissime tradidit. (translation Rackham)

${ }^{18}$ Epitoma rei Militaris. 6.1
} 


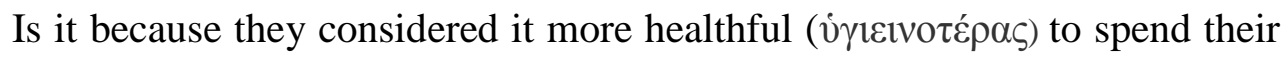
time outside the city than within the city walls? In fact, the Greeks as might be expected have their shrines of Asclepius situated in places, which are clean and high. ${ }^{19}$

Vitruvius wrote similarly about Asclepia, saying that, although all (emphasis my own) sacred precincts were located in healthy neighbourhoods with suitable springs, this was especially the case for healing sanctuaries, because 'when the diseased bodies are transformed from an unhealthy to healthy spot and treated with waters from health-giving springs, they will grow well quicker.' 20

Yet, it is Strabo, who points to a relationship between vision, landscapes, and health. According to him, the Greeks chose sites because of their beauty and strength, but the Romans added aspects the Greeks neglected: aqueducts and sewers, for instance. As an example of Roman ingenuity, he described the Campus Martius in Rome. It was good for exercising, so therefore healthy. ${ }^{21}$ Medical writers at the time promoted the importance of exercise in their texts on the subject of regimen. ${ }^{22}$ Strabo went on to say that the Field of Mars was also notable for its built and natural beauty, and he described the views that could be seen from it: 'it is covered with grass throughout the year, and the crowns of those hills that are above the river and extend as far as its bed, which present to the eye the appearance of a stage painting — all this I say affords a spectacle that one can hardly draw away from. ${ }^{23}$

Comments made by Pliny the Younger about his villas also reveal this relationship between vistas and health. He enjoyed visiting his Apennine Villa because, as he stated,

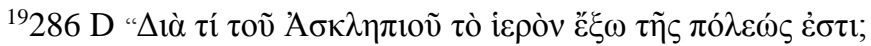

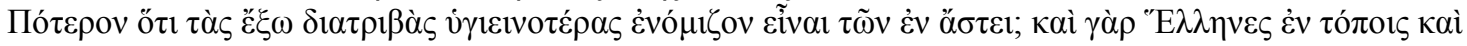

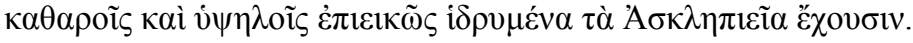

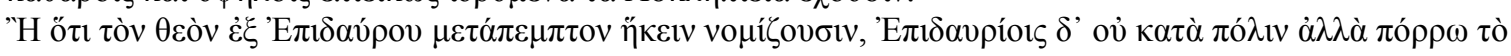

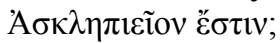

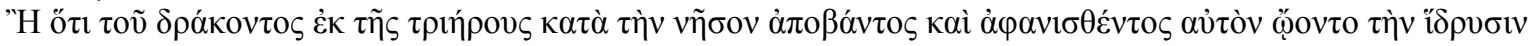

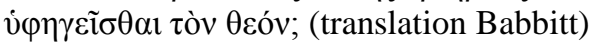

${ }^{20}$ De Arch. 1.2.7 'Naturalis autem decor sic erit, si primum omnibus templis saluberrimae regiones aquarumque fontes in his locis idonei eligentur, in quibus fana constituantur, deinde maxime Aesculapio, Saluti, et eorum deorum quorum plurimi medicinis aegri curari videntur. Cum enim ex pestilenti in salubrem locum corpora aegra translata fuerint et e fontibus salubribus aquarum usus subministrabuntur, celerius convalescent.' (translation Granger)

${ }^{21}$ Geography 5.3 .8

${ }^{22}$ Hipp. On Regimen; and Galen (De Sanitate Tuenda)

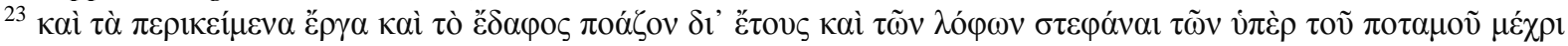

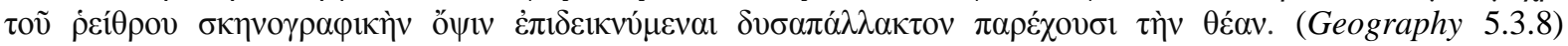
(translation Jones)
} 
'[e]verywhere there is peace and quiet which adds as much to health of the place as the clear sky and pure air. Then I enjoy the best of health both mental and physical. ${ }^{24}$ It appears as if his mention of the clear sky is an admission to his viewing the natural surroundings. Two other letters provide more specific details about the vistas that could be seen from his villas. That to Clusinius Gallus, described his Laurentine Villa, which had views onto the garden and an encircling drive from his dining room. ${ }^{25}$ His letter to Cannius Rufus mentioned a house where it is always spring. It had shady plane trees and a stream with sparkling water that flowed into the lake below it. ${ }^{26}$ All the information Pliny describes concerns multiple sensory experiences: views, sounds, and smells. Again pointing to a link between sensory perception of the environment and the health of the mind and the body.

Spencer has noted in her study on Roman landscapes that Pliny, like other earlier writers - Cato, Varro, and Columella - linked verdant vistas with good health, but the arguments of Spencer tend to focus on the health of the land, rather than people. ${ }^{27}$ Moreover, the data used in her study concentrates on ancient literature, which, as she rightly admits, was written by the wealthy, who shared their advice and experiences with their friends. So, to access the encounters for those who did not record their feelings, I now turn to an examination of the landscapes of healing sanctuaries. One, because they were places intended for the restoration of health, making it likely that their environments were considered important; and two, because most people were welcome to visit these sites rather than a select group of people who put their experiences in writing. Therefore, unless the pilgrims had a visual impairment, they would have encountered similar vistas.

\section{Archaeology and Sanctuaries}

Archaeologists who study landscapes have, for a long time, sought to rethink ancient conceptions and experiences of particular places. $^{28}$ They have devised various ways of studying them, and one of these interpretative methods is concerned with the relationship between the landscape and the activities that took place in them, hence they are referred to as "taskscapes". ${ }^{29}$ Since the term was coined, others have contributed to this discussion by

\footnotetext{
24 5. 6. 45-6 'quod ipsum salubritati regionis ut purius caelum, ut aer liquidior accedit. Ibi animo, ibi corpore maxime valeo' (translation Radice)

${ }^{25} 2.17 .13$

261.3

27 2010: 121

${ }^{28}$ e.g. for an overview see Ashmore and Knapp 1999; Blake 2007; Johnson 2007; Preucel and Meskell 2007;

Osbourne 1992

${ }^{29}$ E.g. Ingold 1993
} 
contemplating different experiences people have within landscapes, for example, it can be gendered, hence, "genderscapes". The term "healthscapes" has recently been added to this category of study, and it concerns human interaction and experiences within healthy environments. ${ }^{30}$

Thinking through someone's feelings of a particular space is ultimately phenomenological, which, from an archaeological perspective, ascertains how someone's senses shaped their impression of being within an area. ${ }^{31}$ Yet, phenomenology, although concerned with sensory stimuli, is argued in recent theoretical archaeological studies to focus only on the subject's sensory experiences and their personal interpretations of the encounter. Archaeologists are now attempting to assess the abilities the materials of objects, or in this case, landscape features, had on those who used or observed them. ${ }^{32}$ To put this simply, the environment is not only experienced by the viewer through the stimulation of the senses, but the environment itself offers encounters to the viewer that can change their conceptions of it. For example, a viewer looking at deciduous trees on a hillside will have a different experience of the trees depending on the season of the year. In the spring and summer the viewer sees various shades of green; in the autumn they see reds, yellows and browns; and in the winter, they see dark branches. The archaeologist would argue that it is the trees and their leaves offering an experience to the viewer, and the viewer will then interpret what the trees "offer" or "afford" to them. Ultimately, landscapes and objects are perceived of as "meshworks" that bring together people, histories, and experiences, for example, because of their ability to offer something and vice versa. ${ }^{33}$ Heft reminds us that landscapes are not simple 'two-dimensional, picture-like images', but they are active and have properties that affect the viewer. ${ }^{34}$ This approach moves beyond the phenomenological analysis in archaeology that searches for a meaning held by the subject, and seeks to locate the abilities of the environment to actively participate with subject's encounters. ${ }^{35}$

To establish the relational process that occurred between the landscape and its user, archaeologists attempt to determine how an ancient landscape appeared and what lived, grew and was constructed within it. Although, as mentioned, there is little evidence for the ancient flora and fauna at the sanctuaries, it is still possible to gain a credible indication of what large-

\footnotetext{
${ }^{30}$ Baker 2013: 133-134

${ }^{31}$ Barrett 1993; Johnson 2007: 134-162; Thomas 1991; Tilley 1994

${ }^{32}$ Jones and Alberti 2013: 16-18

${ }^{33}$ Pollard 2013: 184-5

${ }^{34}$ Heft 2010:17

${ }^{35}$ Alberti 2013: 37-41
} 
scale landscape features were visible from the sites, such as mountains, lakes and seas. This is ascertained by both the descriptions given by ancient visitors' to these sites and an examination of modern maps of the surrounding landscapes. There is always the possibility that trees or structures might have existed that blocked some of the views of the landscape features. However, the size of the hills and mountains suggest that they were visible. Moreover, building orientations indicate that these features were intended to be viewed and were not obscured.

Archaeologically, building orientation and views from temples have been a longstanding issue for debate. This is particularly common for Greek temples, which are almost universally orientated towards the east, with a few rare exceptions. ${ }^{36}$ Arguments tend to state that the temples face a location significant for a deity, as Petsalis-Diomidis indicates. ${ }^{37}$ More recently it has been demonstrated that some Greek temples, which were not directly east facing, were aligned towards specific seasonal constellations that marked festivals to the $\operatorname{god}(\mathrm{s})$ worshipped at the sites. ${ }^{38}$ Ritual activity may have been the primary reason for the location and/or orientation of a temple and sanctuary, as is likely to have been the case at Epidauros, where there is an association with an earlier sanctuary to Apollo on the mountain facing the temple to Asclepius. In addition to the sacred significance, however, simply being exposed to the natural environment contributed to a pilgrim's experience. Hence, we now turn to the descriptions of the landscapes surrounding Asclepia.

There existed many temples and sites dedicated to Asclepius, but only eight are described below because the archaeological information of many other sites is minimal. We know about the existence of temples and sanctuaries dedicated to healing from ancient literature, but the writers did not give many details about their surrounding landscapes. In some cases, no material remains have been located where the writers said a site existed. On the other hand, inscriptions identified some possible areas, but some of these were found with few, if any, standing structures, making it unclear if there was a sanctuary where they were found or if they were simply a dedication to the god in the region. ${ }^{39}$ If a temple did exist, we have no knowledge of where it was placed and what the view from it might have been.

The descriptions I will now give focus on the location and views that can be seen from the sites. Epidauros was the main sanctuary dedicated to the god Asclepius (Fig. 1). The

\footnotetext{
${ }^{36}$ Penrose 1893; Nissen 1906; Aveni and Romano 1994; Liritzis and Vassiliou 2006; Boutsikas 2009; Boutsikas and Ruggles 2011

37 2005: 187

${ }^{38}$ Boutsikas and Ruggles 2011

${ }^{39}$ See Reithmüller 2005; Semeria 1986; and descriptions of sites identified in texts by Edelstein and Edelstein 1988: vol. 1: 370-452
} 
archaeological remains of the sanctuary are located on the eastern side of the Peloponnesus, about 60 kilometers south of Corinth. Travel to the site would have been difficult, specifically for someone who was ill because they would have had to navigate surrounding hills to reach the valley where it was situated. The main route into the sanctuary was reached from the Argolid, and when travelling along the road, two rounded ridges open up to frame a pyramidal peak just before the sanctuary is reached. ${ }^{40}$ To the south, the valley opens and a cleft and a semi-horned ridge enclose the site in full. The pyramidal peak lies ahead above the temple. If one approaches the site from the north (which is from the sea and old town of Epidauros) the ancient way winds between barren and, what Scully refers to, as 'vaguely menacing hills.' The road comes out into the open, climbs slightly and turns directly at the point where the northern propelyon to the site was built. Here, Scully says, 'the tentative curves of the hills are made definite and sure in the curves of the theatre, and the whole visible universe of men and nature comes together in a single quiet order, healed. ${ }^{41}$

Once the site was entered it was located in a low-lying landscape. It had a spring near its main entrance. Inside the boundary the supplicant would have panoramic views up to the surrounding hills. The temple to the deity was oriented eastwards and faced mount Tithion. ${ }^{42}$ Pausanius described a grove existing at the site, so we can also assume that there was greenery visible to the pilgrims. Yet, we cannot say if the mountains were covered with trees at this point in time.

The sanctuary to Asclepius in ancient Corinth was constructed at the edge of a plateau, below the theatre and just on the inside of the city walls. The plateau made the sanctuary higher than the city, allowing breezes from the Gulf to reach it. It is situated to the north of the city, away from its centre, by the spring of Lema. Although the temple is orientated towards the east, the view to the south faces Acro Corinth, a hill with sanctuaries constructed on top of it. ${ }^{43}$

That on the island of Kos was placed on the slope of Mount Dikeos, 100 metres above sea level (Fig. 2). Kos lies off of the coast of western Turkey and across from the ancient city of Halicarnassus. The structures were built on three different levels of the hill, with the eastward facing temple placed at the top. The lower and upper platform levels were surrounded by retaining walls and stoae. The first level of the site has views of gently mounded foothills on the mainland of Turkey. It is also possible to see the mountain ridge behind these hills.

\footnotetext{
${ }^{40}$ Scully 1979: 205

${ }^{41}$ 1979: 206

${ }^{42}$ Tomlinson, R. 1983: 18

${ }^{43}$ Lang 1977; Scully 1979: 207
} 
When climbing to the second level the views become a little wider. Intriguingly, the climb up the steps from the second to the third level is not straight. The steps are curved slightly, possibly to accommodate the view. When the top level is reached, the platforms supporting the lower two levels of the site fall out of view. However, the vista from the temple looks over the sea to the Cone of Halicarnassus, which comes into full sight. ${ }^{44}$

The site at Pergamum in Turkey was, as mentioned, described by Aelius Aristides, who spent a number of years there and kept a record of his dreams, experiences, as well as gave some descriptions of the structures in the sanctuary, giving us a unique insight into life at this place. ${ }^{45}$ Like the other sites described, the sanctuary at Pergamum was located outside the main city. It was constructed in a valley southwest of the Acropolis and it had hills to the east, north, and particularly the west. From the sanctuary, it is possible to see the Acropolis of Pergamum, which was placed on a hilltop above the city and contained a number of altars and smaller sanctuaries. ${ }^{46}$

Some lesser-known sanctuaries to Asclepius have had some archaeological examinations undertaken on them. Even these share the same types of landscape views as the others described. That at Orchomenos was also located on the slope of a hill and had views towards lake Copias and the Mountain of Ptoon, which had an association with Apollo. ${ }^{47}$ In Akragas, located in Sicily, the temple was placed in a valley outside of the town. The temple was surrounded by hills, visible from the site. ${ }^{48}$

The smaller sanctuaries of Asclepius at Athens and Piraeus were both placed on the southern slope of a hill. That at Athens was located beneath the Acropolis and had views towards the hills and mountains surrounding Athens. ${ }^{49}$ The one at Piraeus had views towards the cone of Mount Oros across the Saronic Gulf, and the Gulf itself. ${ }^{50}$

The sanctuary to Amphiaraus at Oropos is located roughly 55 kilometres to the northeast of Athens. It was built in honour of the hero Amphiaraus, and supplicants visited it for prophetic dreams. However, it is included in these descriptions because there is evidence from inscriptions and from Pausanias that pilgrims also went to the site for the rejuvenation of their health. According to Pausanias those healed in the spring would throw silver into it as an

\footnotetext{
44 Scully 1979: 209.

${ }^{45}$ Petsalis-Diomidis 2010; He does discuss surrounding views, but as Petsalis-Diomedes (2008) explains, it is mainly to do with travel and his body within it.

${ }^{46}$ Behr 1968: 27; Petsalis-Diomidis 2010; Scully 1979: 206

${ }^{47}$ Scully 1979: 208

48 Scully 1979: 206

${ }^{49}$ Scully 1979: 204

${ }^{50}$ Scully 1979: 208
} 
offering. A visitor who approached the site from Athens would have reached it by following the spring, which ran through winding hills and a narrow gorge. The views exposed the pilgrim to both the sea in the Gulf of Euboea and the mountains that lay to its east and south. ${ }^{51}$

Table One: Overview of Similar Landscape Qualities

\begin{tabular}{|l|l|l|l|l|l|l|}
\hline Site & $\begin{array}{l}\text { Valley } \\
\text { Location }\end{array}$ & $\begin{array}{l}\text { Hill Top } \\
\text { Location }\end{array}$ & Slope & $\begin{array}{l}\text { Water } \\
\text { Source }\end{array}$ & $\begin{array}{l}\text { View to } \\
\text { Mountain(s) }\end{array}$ & $\begin{array}{l}\text { Sea } \\
\text { View }\end{array}$ \\
\hline Akragas & $\mathrm{X}$ & & & & Hills & \\
\hline Athens & & & $\mathrm{X}$ & $\mathrm{X}$ & Hills & \\
\hline Corinth & & (Plateau) & & $\mathrm{X}$ & $\mathrm{X}$ & \\
\hline Kos & & $\mathrm{X}$ & $\mathrm{X}$ & $\mathrm{X}$ & $\mathrm{X}$ & $\mathrm{X}$ \\
\hline Orchomenos & & & $\mathrm{X}$ & & $\mathrm{X}$ & $\mathrm{X}$ \\
\hline Oropos & $\mathrm{X}$ & & & $\mathrm{X}$ & $\mathrm{X}$ & $\mathrm{X}$ \\
\hline Pergamum & $\mathrm{X}$ & & & $\mathrm{X}$ & $\mathrm{X}$ & \\
\hline Piraeus & & & $\mathrm{X}$ & $\mathrm{X}$ & $\mathrm{X}$ & $\mathrm{X}$ \\
\hline
\end{tabular}

Eight sites are described above (Table One) and they share similar locations. They were either built in valleys or on low-lying slopes, and all were exposed to mountainous views. Four had views of water bodies. The fact that many of the sites are situated in a lower area could also indicate that the movement of the ill was taken into consideration when they were being constructed. To compensate for them being in low-lying areas, if higher areas were thought to be healthier as Vitruvius stated, the views up to the mountains and hills could have given the pilgrim the impression that they were located in a higher and, therefore, healthier region. Moreover, they were all placed in protected surroundings slightly away from the cities or city centres. This could have been done to separate the sick from the healthy, much like the placement of leper hospitals in Medieval Europe. ${ }^{52}$ It might also have been a means of keeping

${ }^{51}$ Scully 1979: 208

${ }^{52}$ Metzler 2012 
the sites quiet and allowing cleaner air to enter them, which would have contributed towards a sense of well-being.

Besides these functional answers for why the sanctuaries were located in similar areas, the corresponding views suggest that there was something fundamental to a pilgrim's experience of the environments of these sanctuaries that was deemed necessary for healing. Cicero argued that views of the mountains and sea provided a pleasant experience. ${ }^{53}$ Since he described the same features found at the sanctuaries, it suggests that others, too, may have found the scenery pleasant.

It can be argued that most of Greece and the Mediterranean have this landscape and the experience was not related to healing sanctuaries alone, which I do not dispute. Many sanctuaries had the comparable landscapes to the Asclepia, and a pilgrim visiting these was likely to have had a similar encounter that benefited their body and mind. Even Vitruvius noted that all sanctuaries were in healthy spots. However, the intention of a pilgrim attending an Asclepion was to be healed, as opposed to those visiting other sites who may have had differing intentions for their pilgrimage. Therefore, the interpretation or experience of the visual encounter may have held a greater significance for health at healing sanctuaries than at other sites. Support for this idea is found in ancient conceptions how vision functioned.

\section{Vision}

Studies on sensory experiences are rapidly developing fields of academic inquiry. The sense of sight receives the most attention in scholarship, mainly because it holds a primacy in the modern west. In particular relationship to landscape studies, vision is deemed essential because, as Feld has shown, it is deeply rooted in the European concepts of landscape, 'which has vision at its centre. ${ }^{54}$ The pre-Socratic philosopher, Democritus, ${ }^{55}$ also described sight as one of the most highly developed senses, as did Aristotle ${ }^{56}$ and Cicero. ${ }^{57}$ According to Aristotle, it was one of the two higher senses along with hearing; while, the senses of smell, taste and touch were categorized as the lower senses.

In spite of being considered one of the higher senses in the present and the past, anthropological and historical analyses have established that the act of viewing was different in the Greco-Roman world. Viewing, as Goldhill argues, is constructed in a socially and

\footnotetext{
${ }^{53}$ Att. 14. 13.1 (translation Shackleton Bailey)

54 2005: 182

${ }^{55}$ For a discussion see Rudolph 2015.

${ }^{56}$ Rudolph 2015; Squire 2015: 12; Aristotle On the Soul 3.3, 429a

${ }^{57}$ On the Orator 2.357
} 
intellectually specific way. ${ }^{58}$ In the Greco-Roman world, vision was thought to be an interactive process, as Squire notes, '[t]o see was to expose oneself to external forces; forces which could impact on the body of the beholder'. ${ }^{59}$ This statement is key to the argument that viewing landscapes impacted on one's health. It directly links to the archaeological theory mentioned previously about the relationship of an object and a subject. Moreover, it ties in with how ancient philosophers described the process of vision.

Theories of vision varied in ancient philosophical thought, but they tend to share the idea that the objects being viewed had direct, and arguably, tangible, contact with the viewer. For example, the pre-Socratics believed that the eyes emitted fire, like the rays of the sun. The rays (or fire) mingled with the object viewed and were reflected in the pools of water surrounding the eyes. ${ }^{60}$ The atomist, Democritus, argued that all objects gave off effluences (thin replications of atoms) that moved from the object into the eyes. ${ }^{61}$ Plato maintained that the eyes let forth a light that mingled with daylight to form a beam. This beam would touch an object, and the eyes would grasp it and understand it. ${ }^{62}$ Although the theories for vision differ, they share the notion that there existed some form of direct visual contact that takes the object (or reflects it in the case of the pre-Socratics) into the eyes and body, and exposing the viewer, as Squire says, to outside forces. Ultimately, the observer was an engaged participant in the processes of seeing as opposed to being merely a spectator. It also indicates a mutual relationship between the subject and the materials of the object being viewed, which, when taken into the body, could affect its health, as Vitruvius noted.

A story by Pausanias links views of a natural feature to both the deity and its health giving power. Hence, he shows that seeing nature was another means of receiving help from and/or having communion with the gods, as the story goes,

Not far from Eileithyia is a precinct of Asclepius, with images of him and of Health. An iambic line on the pedestal says that the artist was Damophon the Messenian. In this sanctuary of Asclepius a man of Sidon entered upon an argument with me. He declared that the Phoenicians had better notions about the gods than the Greeks, giving as an instance that to Asclepius they assign

\footnotetext{
58 2000: 70 in Squire 2015: 4 (note 13)

59 2015: 25. Further information on theories of vision can be found in the following texts: Goldhill 1996; papers in Nelson 2000; Elsner 2007; papers in Blundell 2013.

${ }^{60}$ Rudolph 2015

${ }^{61}$ Nightingale 2015: 55-56

62 Nightingale 2015: 57
} 
Apollo as father, but no mortal woman as his mother. Asclepius, he went on, is air, bringing health to mankind and to all animals likewise; Apollo is the sun, and most rightly is he named the father of Asclepius, because the sun, by adapting his course to the seasons, imparts to the air its healthfulness. I replied that I accepted his statements, but that the argument was as much Greek as Phoenician for at Titane in Sicyonia the same image is called Health and, thus clearly showing that it is the course of the sun that brings health to mankind.

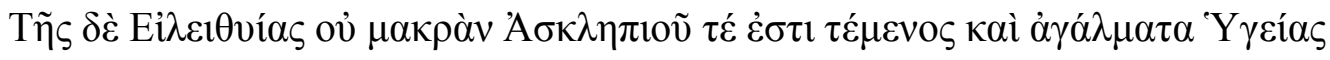

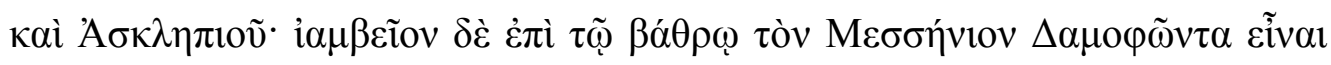

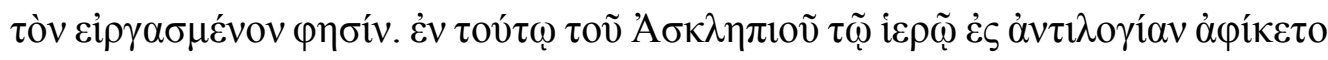

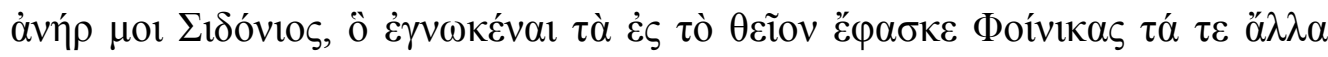

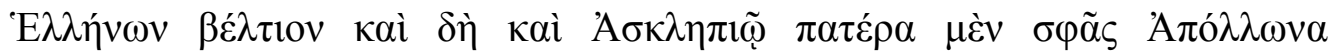

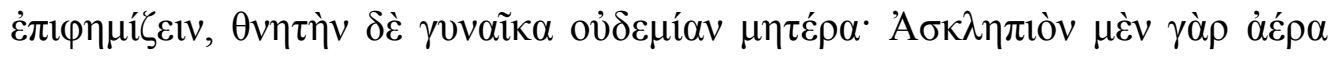

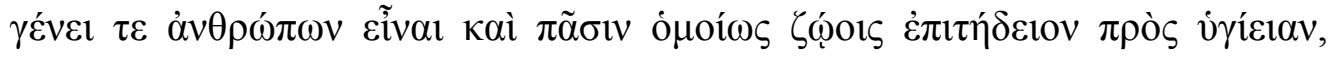

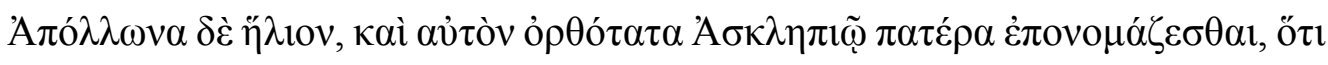

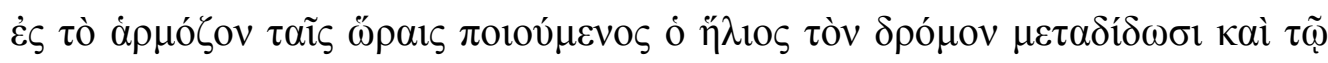

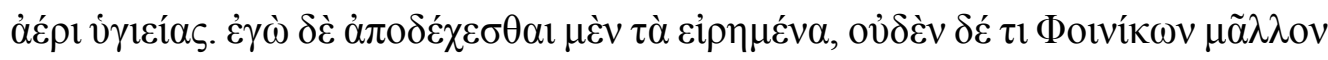

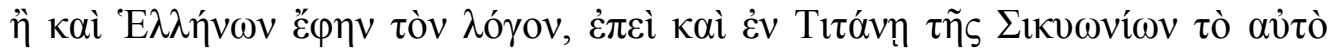

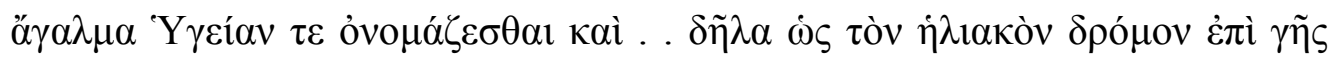

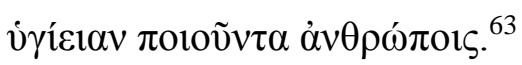

Thus, viewing the course of the sun and believing the sun to be the deity, brings about a visual communication between the viewer and the god that is particularly related to health and the natural world.

Some recent studies in environmental psychology demonstrate that visual stimuli in nature are perceived of as restorative, particular in relation to mental fatigue and stress, ${ }^{64}$ something Pliny the Younger noted in his letters. The environment that soothed the senses: high mountains with clear air and seascapes, would have had a direct correlation on the condition of the body. Seeing these features meant that they were taken directly into the body,

\footnotetext{
${ }^{63}$ Paus. 7.23.7-8 (Trans. Jones)

${ }^{64}$ e.g. Kaplan 1995 and Ratcliff et al. 2013
} 
and, given ancient perceptions of vision, meant that what was being viewed directly contributed to the well-being of a pilgrim at a healing sanctuary, or any sanctuary for that matter.

Viewing landscapes also had the added advantage of allowing the viewer to take particular colours into their body. Greens were healthy to the eyes, and it is possible that blues represented clear air. Therefore, the vegetation on the mountains and clear blue water could have been absorbed into the body through the eyes, enhancing health. ${ }^{65}$

\section{Conclusion}

How then were views of the surrounding landscapes of healing sanctuaries beneficial to the pilgrim? A comparison of the literary descriptions and the landscapes surrounding the sites inform us that there existed an awareness of healthy situations that were not limited to good winds, clean air and clear water, as the Hippocratic text advise. Rather, the landscape itself provided the pilgrim with views of mountains $s$ and seascapes consisting of various colours and lighting effects, as well as the possibility of a deity being observed through nature. The haptic experience of viewing, allowed for a tactile communication between the viewer and the environment. The landscape was brought into the body through vision and alleviated the mind and body of ailments and stress, promoting a sense of well-being that added to the sacred experience of the sites. Thus, the landscapes actively alleviated ailments within the body and mind.

\section{Primary Sources}

Aristotle. On the Soul. Translated by W. S. Hett. Cambridge, MA: Harvard University Press, 1957.

Cato. On Agriculture. Translated by W. D. Hooper, Harrison Boyd Ash. Cambridge, MA: Harvard University Press, 1934.

Cicero. Letters to Atticus. Edited and translated by D. R. Shackleton Bailey. Cambridge, MA: Harvard University Press, 1999.

Cicero. On the Orator: Books 1-2. Translated by E. W. Sutton, H. Rackham. Cambridge, MA: Harvard University Press, 1942.

Hippocrates Airs Waters Places. Translated by W. H. S. Jones. Cambridge, MA: Harvard University Press, 1953.

Hippocrates, Regimen in Health. Regimen 1-3. Dreams. Translated by W. H. S. Jones. Cambridge, MA: Harvard University Press, 1931.

Galen, Galen's Hygiene (De Sanitate Tuenda). Translated by Robert Montraville Green. Springfield, IL: Charles C. Thomas Publisher, 1951/

\footnotetext{
${ }^{65}$ Baker 2011 discusses the colour green and the health of the eyes.
} 
Pausanias. Description of Greece, Volume III: Books 6-8.21 (Elis 2, Achaia, Arcadia). Translated by W. H. S. Jones. Cambridge, MA: Harvard University Press, 1933.

Pliny the Elder. Natural History. Translated by H. Rackham. Cambridge, MA. Harvard University Press, 1950.

Pliny the Younger. Letters, Volume I: Books 1-7. Translated by Betty Radice. Cambridge, MA: Harvard University Press, 1969.

Plutarch. Moralia, Volume IV: Roman Questions. Translated by Frank Cole Babbitt. Cambridge, MA: Harvard University Press, 1936

Varro. On Agriculture. Translated by W. D. Hooper, Harrison Boyd Ash. Cambridge, MA: Harvard University Press, 1934.

Vegetius. Epitome of Military Science. Translated by N. P. Milner. Liverpool: Liverpool University Press, 1993.

Vitruvius. On Architecture. Translated by Frank Granger. Cambridge, MA: Harvard University Press, 1998.

Strabo. Geography, Volume II: Books 3-5. Translated by Horace Leonard Jones. Cambridge, MA: Harvard University Press, 1923

Secondary Sources

Alberti, B. 2013. 'Relational Ontologies'. In Archaeology after Interpretation: Returning Materials to Archaeological Theory, eds. B. Alberti, A. M. Jones and J. Pollard. Walnut Creek, CA: Left Coast Press. 37-42.

Alshire, S. B. 1989. The Athenian Asklepieion: The people, their dedications, and the inventories. Amsterdam: Gieben.

Ashmore, W. and A. B. Knapp (eds.) 1999. Archaeologies of Landscape. Oxford: Blackwell.

Aveni, A. and G. Romano 1994. 'Orientation and Etruscan Ritual', Antiquity 68: 543-563.

Baker, P. 2011. 'Collyrium Stamps: An indicator of regional medical practices in Roman Gaul', European Journal of Archaeology 14 (1-2), 158-189.

Baker, P. 2013. The Archaeology of Medicine in the Greco-Roman World. Cambridge: Cambridge University Press.

Barrett, J. 1993. Fragments from Antiquity: Archaeology of social life in Britain 2900-1200 $B C$. Oxford: Blackwell.

Blake, E. 2007. 'Space, Spatiality, and Archaeology.' In A Companion to Social Archaeology, eds. L. Meskell and R. W. Preucel. Oxford: Blackwell. 230-254.

Blundell, S. Cairns, D. Craik, E. \& Rabinowiz, N. S. (eds.) 2013. Viewing in Ancient Greece (=Helios) 40 (1-2).

Boutsikas, E. 2009. 'Placing Greek Temples: An archaeoastronomical study of the orientation of ancient Greek religious structures', Archaeoastronomy: The Journal of Astronomy in Culture. 21: 4-19. 
Boutsikas, E. and C. Ruggles 2011. 'Temples, Stars and Ritual Landscapes: The Potential for Archaeoastronomy in Ancient Greece', American Journal of Archaeology 115 (1): 55-68.

Edelstein, E. J. and L. Edelstein 1998. Asclepius: Collection and Interpretation. (2 vols.). Baltimore: Johns Hopkins University Press.

Elsner, J. 2007. Roman Eyes: Visuality and subjectivity in art and text. Princeton: Princeton University Press.

Feld, S. 2005. 'Places Sensed, Senses Placed: Towards a sensuous epistemology of environments.' In Empire of the Senses: The sensual culture reader, ed. D. Howes. London: Bloomsbury. 179-191.

Goldhill, S. 1996. 'Refracting Classical Vision: Changing Cultures of Viewing'. In Vision in Context: Historical and contemporary perspectives on sight, eds. T. Brennan and M. Jay. London: Routledge. 17-28.

Goldhill, S. 2000. 'Viewing and the Viewer: Empire and the culture of the spectacle'. In The Body Aesthetic: From fine art to body modification, ed. T. Siebers. Ann Arbor: University of Michigan Press. 41-74.

Heft, H. 2010. 'The Perception of Landscape.' In Innovative Approaches to Researching Landscape and Health, eds. C. Ward Thompson, P. Aspinall and S. Bell. London: Routledge. 9-32.

Howes, D. and C. Classen 2014. Ways of Sensing: Understanding senses in society. London: Routledge.

Hughes, J. 2008. 'Fragmentation as Metaphor in the Classical Healing Sanctuary', Social History of Medicine 21 (2): 217-236.

Ingold, T. 1993. 'The Temporality of Landscape', World Archaeology 25(2): 152-173.

Johnson, M. 2007. Ideas of Landscape. Oxford: Blackwell.

Jones, A. and B. Alberti 2013. 'Archaeology after Interpretation.' In Archaeology after Interpretation: Returning materials to archaeological theory, eds. B. Alberti, A. M. Jones and J. Pollard. Walnut Creek, CA: Left Coast Press. 15-35.

Kaplan, R. 1995. 'The Restorative Benefits of Nature: Toward and Integrative Framework', Journal of Environmental Psychology 15: 169-182.

King, H. 2005. 'Introduction: what is health?' In Health in Antiquity, ed. H. King. London: Routledge. 1-11.

Lang, M. 1977. Cure and Cult in Ancient Corinth. American Excavations in Old Corinth Series Corinth Notes, No. 1. Princeton: American School of Classical Studies at Athens.

Liritzis, I. and H. Vassiliou 2006. 'Were Greek Temples Orientated towards Aurorae?', Astronomy and Geophysics 41: 14-18.

Lo Presti, R. 2012. 'Shaping the Differences: The medical inquiry into the nature of places and the early birth of anthropology in the Hippocratic treatise Airs Waters Places. In Medicine and Space: Body, Surroundings and Borders in Antiquity and the Middle Ages, eds. P. Baker, H. Nijdam and C. van't Land. Leiden: Brill. 169-195.

Metzler, I. 2012. 'Liminality and Disability: Spatial and conceptual aspects of physical impairment in Medieval Europe'. In Medicine and Space: Body, Surroundings and 
Borders in Antiquity and the Middle Ages, eds. P. Baker, H. Nijdam and C. van't Land. Leiden: Brill. 273-295.

Nelson, R. S. (ed.) 2000. Visuality Before and Beyond the Renaissance: Seeing as others saw. Cambridge: Cambridge University Press.

Nightingale, A. 2015. 'Sight and the Philosophy of Vision in Classical Greece: Democritus, Plato and Aristotle. In Sight and the Ancient Senses, ed. M. Squire. London: Routledge. 54-67.

Nissen, H. 1906. Orientation: Studien zur Geschichte der Religion. Berlin: Weidmannsche Buchhandlung.

Osbourne, R. 1992. 'Classical Greek Gardens: Between farm and paradise.' In Garden History. Issues, Approaches, Methods, ed. J.D. Hunt. Washington, D. C.: Dumbarton Oaks Research Library, 373-391.

Penrose, F. C. 1893. 'On the Orientation of Greek Temples', Proceedings of the Royal Society of London 53: 379-384.

Petridou, G. 2013. 'Blessed is He Who Has Seen? The Power of Ritual Viewing and Ritual Framing in Eleusis.' In Viewing in Ancient Greece, eds. S. Blundell, D. Cairns, E. Craik and N. S. Rabinowiz. Helios 40 (1-2). 309-341.

Petsalis-Diomidis, A. 2005. 'The Body in Space: Visual Dynamics in Graeco-Roman Healing Sanctuaries'. In Pilgrimage in Graeco-Roman \& Early Christian Antiquity, eds. J. Elsner and I. Rutherford. Oxford: Oxford University Press. 183-218.

Petsalis-Diomidis, A. 2008. 'The Body in the Landscape: Aristides Corpus in the light of The Sacred Tales. In Aelius Aristides between Greece, Rome and the Gods, eds. W. Harris and B. Holmes. Leiden: Brill. 131-150.

Petsalis-Diomidis, A. 2010. Truly beyond Wonders: Aelius Aristides and the Cult of Askepios. Oxford: Oxford University Press.

Pollard, J. 2013. 'From Ahu to Avebury: Monumentality, the social and relational ontologies.' In Archaeology after Interpretation: Returning Materials to Archaeological Theory, eds. B. Alberti, A. M. Jones and J. Pollard. Walnut Creek, CA: Left Coast Press. 177-196.

Preucel, R. W. and L. Meskell 2007. 'Places'. In A Companion to Social Archaeology, eds. L. Meskell and R. W. Preucel. Oxford: Blackwell. 215-229.

Ratcliffe, E. B. Gatersleben, and P. T. Sowden 2013. 'Bird Sounds and their Contributions to Perceived Attention Restoration and Stress Recovery', Journal of Environmental Psychology 36: 221-228.

Reithmüller, J. W. 2005. Asklepios: Heiligtümer und Kulte. Heidelberg: Verlag Archäologie und Geschichte.

Rudolph, K. 2015. 'Sight and the PreSocratics: Approaches to Visual Perception in early Greek Philosophy.' In Sight and the Ancient Senses, ed. M. Squire. London: Routledge. 36-55.

Scully, V. 1979. The Earth, the Temple and the Gods. New Haven: Yale University Press.

Semeria, A. 1986. 'Per un Censimento degli "Asklepia” della Grecia Continentale delle Isole,' Annali della Scuola Normale Superiore di Pisa. Classe ai Lettere a Filosophia 3, 16 (4) 939-958. 
Spencer, D. 2010. Roman Landscape: Culture and identity. Cambridge: Cambridge University Press.

Squire, M. 2015. 'Introductory Reflections.' In Sight and the Ancient Senses, ed. M. Squire. London: Routledge. 1-35.

Thomas, J. 1991. Rethinking the Neolithic. Cambridge: Cambridge University Press.

Tilley, C. 1994. A Phenomenology of Landscape: Places, Paths, and Monuments. Oxford: Berg.

Tomlinson, R. A. 1976. Greek Sanctuaries. London: Book Club Associates.

Tomlinson, R. A. 1983. Epidauros. Austin: University of Texas Press.

Wickkiser, B. L. 2008. Asklepios, Medicine, and the Politics of Healing in Fifth-Century Greece. Baltimore: Johns Hopkins University Press.

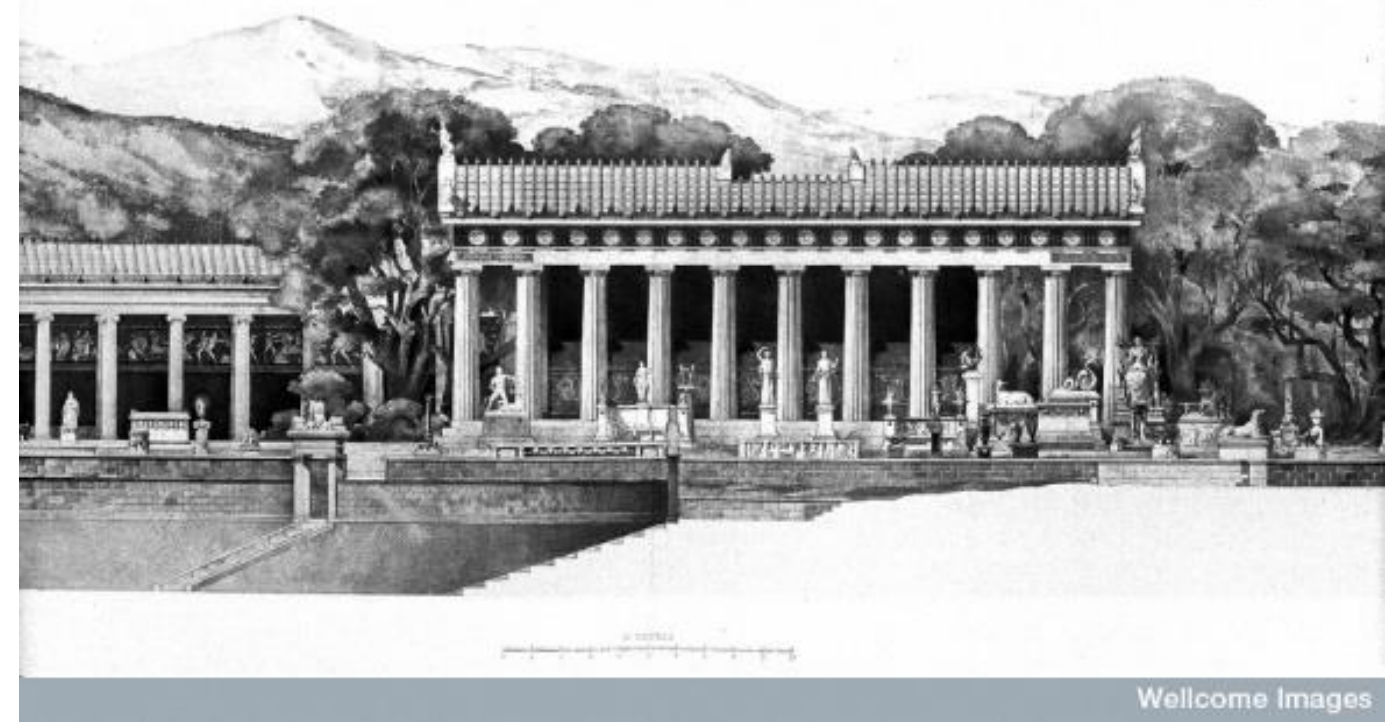

Figure One. Landscape drawing of Epidauros.

Wellcome Library, London

Reconstruction of the tholos at Epidaurus (centre) Defrasse, Alphonse \& Lechat, Henry Librairies-Imprimeries Reunies Paris. 1895 


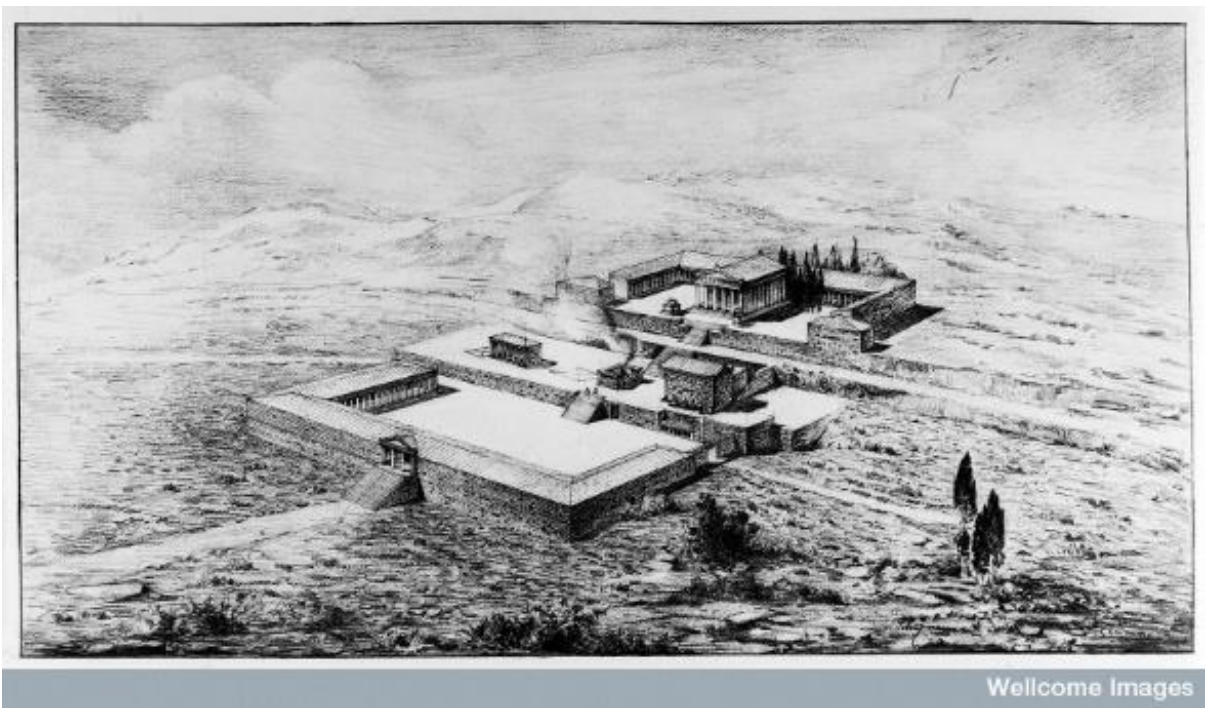

Figure Two: The surrounding landscape of the Asclepion at Kos.

Wellcome Library, London

The Asclepion in the Hellenistic period, from north-west, Kos

By: Herzog, Rudolf

Published: Berlin 1932 